\title{
THE FAMILY'S EXPERIENCE OF HAVING A MENTALLY ILL FAMILY MEMBER
}

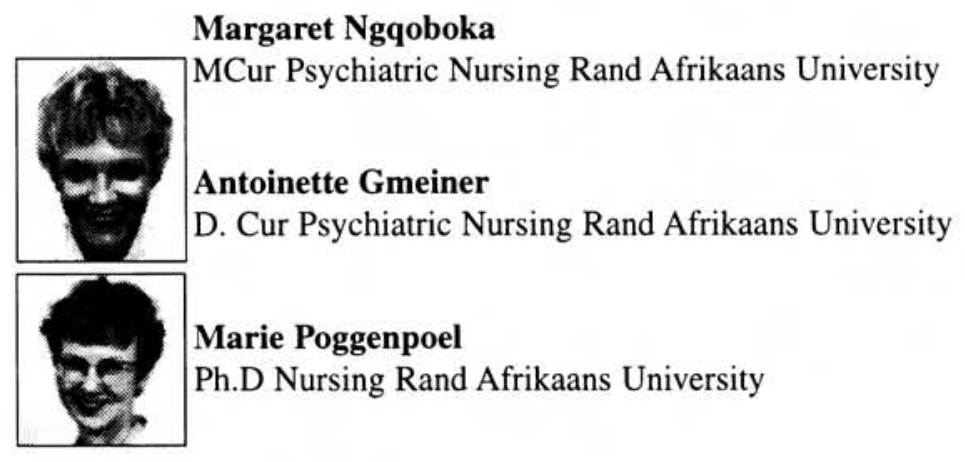

\section{ABSTRACT}

The purpose of this study was firstly to explore and describe the experience of families with a mentally ill family member and secondly to describe guidelines (based on the results obtained) for the advanced psychiatric nurse practitioner to assist families in mobilizing their resources to facilitate the promotion, maintenance and restoration of their mental health as an integral part of health. A qualitative, exploratory, descriptive and contextual research design was used and Guba's model of ensuring trustworthiness in qualitative research was applied. The phenomenological strategy was used to collect data from a purposive sample of respondents, consisting of five families.

Three themes emerged from the analysis of respondents' results and were divided in three stages: The first stage is the onset of mental illness, the second stage begins when the family starts seeking help for the mentally ill family member and the third stage is the post-treatment of the family member and when he/she is back home with his/her family. From these results, guidelines were deducted to assist families in mobilising their resources too facilitate their mental health.

\section{OPSOMMING}

Die doel van hierdie studie was eerstens om die belewenis van gesinne wat ' $n$ geestesongestelde gesinslid het, te verken en beskryf en in die tweede plek om riglyne te beskryf vir die gevorderde psigiatriese verpleegpraktisyn om hierdie gesinne the help in die mobilisering van hulpbronne om hul geestesgesondheid as integrale deel van gesondheid te bevorder, te handhaaf en te herstel. Hierdie riglyne is gebaseer op die resultate bekom deur onderhoude. 'n Kwalitatiewe, verkennende, beskrywende en kontekstuele ontwerp is gevolg en Guba se model vir vertrouenswaardigheid in kwalitatiewe navorsing is aangewend om die vertrouenswaardigheid van die studie te verhoog. 'n Fenomenologiese strategie is gevolg om data in te samel. Die steekproef is doelgerig geselekteer en het bestaan uit vyf gesinne.

Drie hooftemas is geïdentifiseer en is beskryf in drie fases: Die eerste fase is met aanvang van die gesinslid se geestesongesteldheid, die tweede stadium begin wanneer die gesin begin hulp soek vir die geestesongestelde gesinslid en die derde stadium is die na-behandelingstadium van die gesinslid wanneer hy/sy terug is by sy/haar gesin. Riglyne is uit die resultate gederiveer om gesinne te help om hulpbronne te mobiliseer om hul geestesgesondheid te bevorder.

\section{BACKGROUND}

Studies revealed the fact that there is a need for improved mental health care in South Africa (Center for the Study of Health Policy, University of the Witwatersrand, 1991:35).

Mental health care is often seen as secondary to physical health care and is relegated to fringes of health care and planning. Facilities within mental health care lag far behind other areas of health care and for the majority (e.g. the rural areas of the Eastern Cape Province) there is no care at all. This includes a lack of knowledge of the families of mentally ill persons about the care of their mentally ill members. Because of this lack of knowledge, the families tend not to accept their mentally ill members back høme.
In a study conducted by Uys \& Zulu (1996:26-230), it was revealed that the families of psychiatric patients experience financial hardship, since so few of the psychiatric patients receive disability grants. Most families do not visit their mentally ill family members or attend the clinic with them, therefore contact between them and the potentially helpful professional staff seems limited. These patients are then sent home where the totally unprepared family members must care for them. It is the responsibility of the health care workers to assist them and especially to provide them with guidelines to assist their mentally ill family members.

Mental health services, like all other services, are fragmented and ill equipped to intervene effectively. Resources are mis- 
managed and poorly distributed. The available services are neither appropriate, nor accessible to the majority of the population; the situation in the rural areas is particularly bad (New Health Act, 1997:135).

There is a very high "revolving door syndrome" in and out of the psychiatric hospitals in South Africa and this seems to be the result, in part, from inadequate community care. If community care and facilities are inadequate for those who need psychiatric care, patients may make a nuisance of themselves and are forced into institutional care (Center for the Study of •Health Policy, University of the Witwatersrand, 1991:36).

\section{PROBLEM STATEMENT, RESEARCH QUESTIONS AND OBJECTIVES}

As a psychiatric nurse working in a psychiatric hospital the researcher has observed that most of the hospital's patients are readmissions. Their case studies reflect that some of these patients are brought to the hospital by police and social workers, some by state escorts and the public and are perceived as being dangerous to themselves and the public.

The patients reveal the fact that when they are discharged they discontinue treatment because there are no clinics nearby. It is difficult for them to go to other clinics because they do not have money to use public transport.

One family told the researcher that their mentally ill family member was unmanageable at home. That was the reason why they had to have him readmitted. They were afraid of him because he was destructive to property during the onset of his mental illness. He assaulted his wife and children. They therefore found it very difficult to accept him back home.

In lieu of the above the following research questions were asked:

- How do families experience having a mentally ill family member?

-What guidelines can be described for an advanced psychiatric nursing practitioner to assist the family in mobilising resources to facilitate the promotion, maintenance and restoration of mental health as an integral part of health (wholeness)?

Based on these research questions the following objectives were identified:

- To explore and describe the experience of families having a mentally ill family member (as patient).

- To describe guidelines for the advanced psychiatric nursing practitioner to mobilise resources for the promotion, maintenance and restoration of the family's mental health as an integral part of health (wholeness).

\section{RESEARCH DESIGN AND METHOD}

A qualitative, exploratory, descriptive and contextual research design (Mouton \& Marais, 1990:49-121; Mouton \& Marais, 1992:45, 175) was utilised to conduct this research. The focus was to obtain data that would facilitate the understanding of the effect of mental illness on the family (their experience).

The research was conducted in two phases. The research sample, data collecting, data analysis, literature control and ethical measures utilised will be described and thereafter the method to describe the guidelines for the advanced psychiatric nursing practitioner to mobilise resources for promotion of the family's mental health.

\section{Phase one}

The exploration and description of the experience of families with mentally ill family members.

In this phase the respondents who met the sampling criteria were identified purposively (Cresswell, 1994:15) to participate in the study.

- The sample of this study comprised a total of five families as data was saturated by means of repeating themes. All families had mentally ill family members who were readmitted to a certain psychiatric hospital in the rural black area of the Eastern Cape Province. They all spoke and understood both English and Xhosa, and these families were living or have lived with their mentally ill relatives. All the families were interviewed in their home environment and the researcher went to all families with mentally ill family members to gain permission and introduce herself as a research student.

The families interviewed displayed the following characteristics:

- One family comprised of both parents and a brother of the mentally ill family member.

- One was a single parent family with only the mother present.

- Another comprised a daughter and grandchildren of the mentally ill family member.

- Another family consisted of a brother and the wife and children of the mentally ill patient.

- The last family comprised grandparents, their son and daughter who was the mother of the mentally ill child.

Most of these patients had no clear psychiatric diagnosis, but it seemed as though the most consistent diagnoses were that of schizophrenia as they were all chronic, long-term patients on medication.

Semi-structured, in-depth phenomenological interviews (Kvale, 1983:184) were conducted as a method of data gathering. Interviews were recorded using a dictaphone and were then transcribed verbatim (Burns \& Grove, 1993:578-581). 
The purpose of these interviews was to gather uninterrupted descriptions of the life-world of participants with respect to interpretation of the meaning of the described phenomena (Kvale, 1983:174). In this study it was the in-depth experience of families having a mentally ill family member.

One central question was posed namely: "Please tell me how you experience having a mentally ill family member?" The interviewer created a context where the respondents could speak freely and openly by utilising communication techniques such as minimal response, probing, clarification, reflecting, summarising and paraphrasing. During the interviews the interviewer used bracketing (putting preconceived ideas aside) and intuiting (focussing on the lived experience of the respondents) regarding mentally ill members in the family. Interviews were conducted until the data was saturated as demonstrated by repeated themes and not by the amount of interviews done.

The interviewer took field notes based on observations made during interviews. These field notes addressed the interviewer's observation, personal experience, methodological issues and theoretical notes. More importantly the field notes are for remembering the observations, retrieving and analysing them (Wilson, 1989:434).

Data was analysed using Tesch's descriptive method (Cresswell, 1994:154-156). An independent coder analysed the data separately from the researcher (Cresswell, 1994:158; Krefting, 1991:216). After a consensus discussion between the independent coder and the researcher, the identified themes were presented.
A literature control was done to verify the research study and to establish the relevance and uniqueness of the research (Woods \& Catanzaro, 1988:135).

\section{Phase two}

Guidelines for the advanced psychiatric nursing practitioner to assist the families with mentally ill family members in mobilising their resources to facilitate the promotion, maintenance and restoration of their mental health as an integral part of health (wholeness).

During this phase data collected from the informants and the literature control was used as a basis for describing guidelines. The guidelines were then discussed with family members for the purpose of validating them.

\section{MEASURES TO ENSURE TRUSTWORTH- INESS}

Measures to ensure trustworthiness were applied. Guba's model as summarised in Krefting (1991:215-222) suggests strategies of credibility, transferability and dependability and confirmability. The activities in achieving credibility were prolonged engagement in the field, keeping reflexive field notes, member checking by follow-up interviews with participants, the researcher's authority and structural coherence.

Dependability was achieved by dense description of the data, audit trail, peer examination and a code-recode procedure. Transferability was achieved by purposive sampling, dense description of methodology and literature control to maintain transparency. Confirmability was by audit trail and reflexivity (Krefting, 1991: 215-222) (See table 1).

\section{TABLE 1: Strategies to ensure trustworthiness}

\begin{tabular}{|c|c|c|}
\hline Strategy & Criteria & Applicability \\
\hline \multirow[t]{6}{*}{ Credibility } & Prolonged engagement & $\begin{array}{l}\text { Contact the patients as readmissions in a psychiatric hospital. } \\
\text { Trace their families; spend time with family members before the inter } \\
\text { view to build rapport. Allow time for the respondents to verbalise } \\
\text { experiences. }\end{array}$ \\
\hline & Reflexivity & Taking field notes. \\
\hline & Member checking & $\begin{array}{l}\text { Follow-up interviews with participants. Literature control on caring for } \\
\text { mentally ill patients and its impact on the guidelines. }\end{array}$ \\
\hline & Peer examination & The services of colleagues will be required. \\
\hline & Authority of research & $\begin{array}{l}\text { The researcher has undergone previous training in research methods. } \\
\text { The study will be supervised by a person with a doctorate in psychiatric } \\
\text { nursing and a co-supervisor who is a professor in psychiatric nursing } \\
\text { and has extensive experience in conducting qualitative research. }\end{array}$ \\
\hline & Structural coherence & $\begin{array}{l}\text { The focus will be on families' experiences. Results will be reflected } \\
\text { within the Nursing for the Whole Person Theory. }\end{array}$ \\
\hline \multirow[t]{2}{*}{ Transferability } & Nominated sample & $\begin{array}{l}\text { The sampling method will be purposive - data source regarding the } \\
\text { experiences of having a mentally ill patient in the family. }\end{array}$ \\
\hline & Dense description & $\begin{array}{l}\text { Complete description of methodology and literature control to maintain } \\
\text { transparency. }\end{array}$ \\
\hline \multirow[t]{4}{*}{ Dependability } & Audit Trail & Keeping personal logs and reflexivity notes. \\
\hline & Dense description & Research methodology fully described. \\
\hline & Peer examination & Independent checking and supervision by experts. \\
\hline & Code-recode procedure & $\begin{array}{l}\text { Consensus discussion between researcher and independent coder for } \\
\text { placing of themes and identifying inferences. }\end{array}$ \\
\hline \multirow[t]{2}{*}{ Confirmability } & Audit trail & As mentioned above. \\
\hline & Reflexivity & As mentioned above. \\
\hline
\end{tabular}




\section{ETHICAL MEASURES}

Ethical measures were adhered to during this research. These include informed consent of the respondent's privacy; ensuring confidentiality and anonymity and providing the families with results (SANA, 1991:5).

\section{RESULTS AND DISCUSSION OF RESULTS}

Table 2 shows an overview of the major stages, themes and categories from the family's description of their experiences of having a mentally ill family member.

- The first stage is the onset of mental illness in the family.

- The second stage is when the family takes action such as sending the mentally ill member for help to e.g. traditional healers and psychiatric hospital(s).

- The third stage is when the mentally ill family member is discharged from hospital.
The discussion of findings will be based on stages, themes and categories as set out in table 2 .

In discussing the results, relevant data from the literature will be incorporated, although no studies were found in the literature that focused specifically on the family's experience of having a mentally ill family member within this specific context.

The findings are discussed below.

\section{First stage}

\section{Negative emotions}

- All families experienced shock during the onset of the mental illness of their family member since they described it as very unexpected. "Great shock, yes it was a great shock. We couldn't believe it." Another family described it as follows: "We never knew it could happen to us."

TABLE 2: An overview of stages, themes and categories of the experience of families with mentally ill members.

\begin{tabular}{|c|c|c|}
\hline Stages & Themes & Categories \\
\hline \multirow[t]{4}{*}{$\begin{array}{l}\text { First stage: the onset } \\
\text { of mental illness in the } \\
\text { family. }\end{array}$} & $\begin{array}{l}\text { 1.1 Negative emotions related to mental } \\
\text { illness in the family. }\end{array}$ & $\begin{array}{l}\text { Shock } \\
\text { Guilt } \\
\text { Fright } \\
\text { Anger } \\
\text { Guilt } \\
\end{array}$ \\
\hline & $\begin{array}{l}\text { 1.2 Social effects related to behaviour displayed } \\
\text { by the mentally ill member. }\end{array}$ & $\begin{array}{l}\text { Isolation from other families, friends and } \\
\text { significant others } \\
\text { Stigmatisation }\end{array}$ \\
\hline & $\begin{array}{l}\text { 1.3 Sense of loss related to loss of responsible member. } \\
\text { Loss of money spent on treatment. } \\
\text { Loss of property due to the destructive behaviour } \\
\text { displayed by the mentally ill family member. }\end{array}$ & $\begin{array}{l}\text { Loss of property } \\
\text { Financial loss } \\
\text { Loss of responsibility } \\
\text { Loss of property due to destructive behaviour }\end{array}$ \\
\hline & $\begin{array}{l}\text { 1.4 Psychological defence mechanisms related to } \\
\text { finding ways to cope with the stressful situation. }\end{array}$ & $\begin{array}{l}\text { Denial } \\
\text { Blame }\end{array}$ \\
\hline \multirow[t]{4}{*}{$\begin{array}{l}\text { Second stage: seeking } \\
\text { help for the mentally ill } \\
\text { family member. }\end{array}$} & $\begin{array}{l}\text { 2.1 Negative emotions related to suspicion, burden, } \\
\text { and fear for their life and doubt. }\end{array}$ & $\begin{array}{l}\text { Feeling of persecution } \\
\text { Frustration } \\
\text { Distrust } \\
\text { Uncertainty / insecurity } \\
\text { Hope }\end{array}$ \\
\hline & $\begin{array}{l}2.2 \text { Physical exhaustion related to lack of sleep and } \\
\text { rest. Anxiety of not knowing what is going to } \\
\text { happen next. }\end{array}$ & $\begin{array}{l}\text { Chasing and restraining a person who is } \\
\text { restless, aggressive and who will not sleep }\end{array}$ \\
\hline & $\begin{array}{l}\text { 2.3 Financial loss related to money spent on person's } \\
\text { treatment. }\end{array}$ & $\begin{array}{l}\text { Money spent on traditional healers } \\
\text { Transporting a inental person to and from } \\
\text { treatment areas }\end{array}$ \\
\hline & $\begin{array}{l}2.4 \text { Helplessness related to lack of funds and not } \\
\text { knowing what to do next. }\end{array}$ & Despair \\
\hline $\begin{array}{l}\text { Third stage: Post - } \\
\text { treatment of the family } \\
\text { member and back home }\end{array}$ & $\begin{array}{l}\text { 3.1 Emotions related to previous assaults by the } \\
\text { mentally ill family member. } \\
\text { with his/her family. }\end{array}$ & $\begin{array}{l}\text { Fear } \\
\text { Mistrust }\end{array}$ \\
\hline . & $\begin{array}{l}\text { 3.2 Social effects related to broken relationship. } \\
\text { Relationship problems with family members } \\
\text { related to negative behaviour he/she displayed } \\
\text { in the family. }\end{array}$ & $\begin{array}{l}\text { Lack of trust } \\
\text { Doubt if completely cured } \\
\text { Cannot be responsible anymore }\end{array}$ \\
\hline
\end{tabular}


This shock they experienced is supported by Searll $(1995: 128)$ stating that there are many people suffering from mental illness and their sometimes shocking behavior is no more than a symptom of their affliction.

- All families were frightened by the behavior of their mentally ill family members. Some of the families described it as follows: "Her aggressive and assaulting behavior frightens us. She was aggressive to her mother and assaulting to children in so much that I had to be available as a father to protect them from her."

Searll (1995:131), stating that many families have the frightening experience of realising that they have no control over their mentally ill family member, describes this fright, especially if he/she assaults them.

- Anger related to destructive and assaulting behavior displayed by the mentally ill family member and also feelings of guilt on the part of the family. All families experienced guilt towards their mentally ill family members and themselves. They described it as follows: "To me it is as if this mental illness should never have started if she was at home. It started when she was out to these salvation churches. I even told her, look at this salvation of yours. I've told you long ago that I do not like this salvation business but you would never listen to me. Look at what you are now."

The anger and frustration experienced by the families are also normal. It is very common for families of mentally ill patients to feel intensely angry, not only with their mentally ill family members, but also with each other, (blaming) God, and anyone they can think of to blame (Searll, 1995:131).

\section{Social effects}

Social effects related to behavior displayed by the mentally ill family member such as undressing in public, physical and verbal aggression.

- All families experience isolation or distancing by their extended family, friends and significant others. They described their feelings as follows: "We felt as if we were alone in an island, there was nobody to turn to; friends and family were at a distance, there was no one visiting us."

The researcher acknowledges the social isolation families experience because the myth, especially in the rural black community, that mental illness is infectious, still exists. Mental illness in the rural black communities is still associated with possession by demons and people are therefore afraid to come near a mentally ill person. They fear that they might also be affected. Mbiti (1991:165-168) writes much about the fact that when something goes wrong in the family or someone gets ill, it is caused by some form of witchcraft and possession by demons.

There is a stigma related to abusive language and assaulting behavior by the patient. Rawlins, William \& Beck (1993:63) describe this subcategory of social isolation as any attribute that differs or discredits, in the categorisation scheme employed by all societies - large and small. The mentally ill, as well as many others, who do not meet selected norms of social groups, are prominent in the discredited group. Mental illness is incorrectly portrayed as flamboyant and unmanageable, with none of the sympathy accorded to other chronic situations (Fawcett, 1993:348).

- They described stigmatisation as follows: "As she is reporting that at school they look at her as if she is still mentally ill, and this is troubling her. I am afraid that this is going to affect her as this attitude is worrying her a lot."

\section{Sense of loss}

- All families experience the loss of loved ones that cannot be held responsible for their actions anymore, as well as a loss of trust and a loss of money spent on treatment. "I've lost my mother and my father, and my brother was the only one I could discuss my problems with. I trusted him and he trusted me. Now there he is, I've no one to turn to." One family said: "My daughter was responsible for her children when she was still alright. She was working, feeding her own children. Now I am alone. I am only earning R350, 00 per month. I feel as if I am in an island."

Rawlins, William \& Beck (1993:238) support the loss by saying it is an inevitable dimension of the human experience. Loss is an actual or potential state in which a valued object or person is lost or changed. The manner in which each individual perceives loss depends on the value placed on the lost object or person.

\section{Psychological defense mechanisms as a way of coping with stressful situations}

Perko and Kreigh (1998:117) define defense mechanisms as intra-psychic devices that serve as the first line of ego protection and defense. They are adjustment and coping techniques that provide the individual with a ready-made constructive means to maintain emotional equilibrium. The primary functions of these coping devices are to facilitate the resolution of emotional conflict, provide relief from stress, cushion emotional pain, avoid or alleviate anxiety.

- All families felt that they could not cope with their situations. They therefore used denial as a way of coping with their stressful situations. One family described this as follows: "I couldn't believe this. I really could not believe that our daughter was mentally ill, especially after spending a lot of money on her education. How can she be like this after passing standard ten?"

Rawlins, Williams \& Beck (1993:902) state that denial is a defense mechanism used to resolve emotional conflict and allay anxiety by disowning thoughts, feelings, wishes, needs or external reality factors that are consciously intolerable. Blaming is a coping strategy used to shift responsibility to someone or something.

- All the families blame themselves for the occurrence of mental illness in their families. One family described this 
as: "We didn't know what wrong have we done so that this child is like this. Maybe it is this church because she fell ill while she was attending this salvation church of hers." Families could not bear the pain of having a mentally ill member. To cope with this situation they used blame and guilt to try and explain what happened.

SANCA (1987:3) supports this by saying the condition is not denied, but its cause is placed on someone else or something. In this way the responsibility is shifted to someone or something.

\section{Second stage}

\section{Seeking help for the mentally ill member}

- Families experienced feelings of persecution related to suspicion, burden, fear for their lives and doubt. One family felt that people who were jealous that their child never failed up to standard ten was persecuting them. They described these feelings as follows: "Why is it that whenever we are having an educated child we are going to loose that child? Our two children have died suddenly being knocked by cars. Now this one has survived that, they see that she must be mentally ill. They are bewitching us, they do not want us to have anything beautiful."

This is supported by Searll (1995:130) when she says families may even fear for their own safety.

-All the families experienced frustration because of expenditure and the behavior displayed by their mentally ill members. They described this as follows: "I've taken my brother to many places for help, I even took him to a mental hospital but he absconded during nurse's strike. I don't have any money to take him back to hospital." The families felt frustrated because they could not assist their family members because of lack of funds.

Sidelau (1992:60) describes frustration as an unpleasant affect, characterised by built-up emotional energy when needs, wishes and/or others obstruct desires, one's own ability or a given situation.

\section{Negative emotions}

- Distrust, uncertainty and insecurity related to assault are experienced. All respondents experienced mistrust, uncertainty and insecurity towards their mentally ill family members. They described this as follows: "I was shocked when I saw her coming home. I thought it was still early for her to be discharged. I couldn't trust her because she was aggressive towards me" and "That I am staying here, I am hiding away from him. He chased me with a knife last Christmas. I don't trust that he cannot do me any harm once he knows that I am staying here." Trust was lost during assaults by the members.

Johnson (1993:71) states that just one betrayal may create distrust and once established, distrust is extremely resistant to change.
- The family's hope rises if their mentally ill family member is entrusted to hospital care as opposed to other forms of caring. All respondents experienced a sense of hope despite their negative feelings about their mentally ill members. They described this as: "I hoped my brother would be cured if he stayed in hospital. He would be discharged with treatment so that he continues taking it. He is not so bad that he cannot be cured. He does not undress in public as other mentally persons would do." Despite all the negative emotions, families have hope for their members.

Rawlins \& Beck (1993:264) says that a person who hopes will persevere, and that perseverance is the ability to keep on working towards solutions that will ease distress or change one's condition.

\section{Physical exhaustion}

- Physical exhaustion due to lack of sleep and rest was experienced. All families experienced physical exhaustion due to lack of sleep and rest, chasing and restraining someone whom is restless. They described this as follows: "We couldn't sleep days and nights. We were watching her, as she wanted to run away. I had to be next to her mother for protection as she wanted to bite her."

\section{Third stage}

Other themes in the third stage have already been described in the previous stages. Only the subcategory of social effects, i.e. relationships, will be discussed here.

\section{Social effects}

- Relationship problems within a family relate to the negative behavior a person displays in the family. The relationship was disturbed between the family and their mentally ill family member because of lack of trust and doubt whether or not the patient was completely cured. The families described this as follows: "I don't trust him, I don't want him anymore here at home. Even if he can be said to be cured I don't trust him. My body is full of scars from stab wounds because of him. Here at home I've got small children. What if he comes while we are not there and injure a child?"

Searll (1995:124) states that mental illness can wreak havoc in a family. The destructive behavior of a mentally ill family member can cause trauma, tension, guilt, envy and bitterness. It can tear marital relationships to shreds and cause resentment and even hatred between siblings.

\section{Patterns of interaction within Nursing for the Whole Person Theory}

There are certain patterns of interaction between internal and external environments that are implied in the Nursing for the Whole Person Theory (Oral Roberts University, Anna Vaughn School of Nursing, 1990:136-142; Rand Afrikaans University, Department of Nursing Science, 1993:7-9). These patterns of interaction reflect the mental health status 
of the family as indicated by the following:

- Emotional disturbances as evidenced by feelings of shock, fright and anger: "Great shock, yes. It was a great shock... We couldn't believe it."

- Fear for their own lives: "One has to be careful he doesn't want to see children. He would take a child and bang her head against the wall. As for me, he doesn't want even to look at me."

- Broken relationships as evidenced by distrust of the mentally ill member by his family: "That I am staying here. I am hiding away from him, he chased me with a knife last Christmas. I don't trust that he cannot do me any harm once he know that I stay here."

- One family member does not want her mentally ill family member back home because he stabbed his sister-in-law.

- Change in their financial state as evidenced by spending money on the mentally ill family member's treatment.

\section{CONCLUSION AND RECOMMENDATIONS (GUIDELINES) WITH REGARD TO THE INTERVIEWS WITH FAMILIES}

It is clear from the results of these interviews with families that the families experience emotional pain, loss, social isolation, feelings of persecution, frustration, uncertainty and insecurity, distrust and physical exhaustion. Their perceptions of mental illness are that a person cannot be cured from it and therefore he/she cannot be trusted anymore.

They question the future of their mentally ill family members. They would rather have them kept in mental hospitals forever. They see them as useless people who cannot be responsible. However, despite these negative feelings they still hope that they can be cured if they can be kept in hospital for a period of time and discharged with treatment. All families who participated in this study experienced various emotions and it was found that use was made of defense mechanisms in an effort to cope with their feelings. The guidelines for the advanced psychiatric nurse practitioner are therefore described in an effort to assist the families with mentally ill family members in the black rural areas of the Eastern Cape Province to mobilise their resources to facilitate promotion, maintenance and restoration of mental health as an integral part of health (wholeness).

The families in this study are viewed, according to Nursing for the Whole Person Theory (Rand Afrikaans University, 1992:2-7) as a whole - body, mind and spirit - and function in an integrated bio-psychosocial manner to achieve their quest for wholeness. The family seeks to interact with the internal and external environment in a holistic manner.
In view of the above conclusions the following guidelines for operationalisation are recommended. Guidelines for this study propose the development of support groups for families by families. These guidelines are described according to the nursing process, namely the health diagnosis, aim, and nursing intervention or strategies used to intervene with the existing family problems as outlined in table 3 .

\section{Experience: First stage - onset of mental illness}

Shock related. This is the onset of the mental illness and the family experience negative feelings and denial of the fact that the family member is really mentally ill. They also experience fright and anger related to the assault from the mentally ill family members. The social effect, where they are isolated from friends and significant others, also has a negative impact on the families.

\section{Aims}

- To accept their mentally ill family member without prejudice.

- To be more relaxed and to be mobilised to take constructive action.

- To be able to channel anger in a more constructive way.

- To be able to relieve isolation and mobilise support systems - that is friends and other important relationships.

The purpose of group therapy is to facilitate positive and creative change (Rawlens, William \& Beck, 1993:561). Developing an awareness of self and encouraging positive and creative change is supported by challenging some of the truths in a group situation that are believed to be reality (Van Reenen, 1994:84-87). Family members are encouraged to learn new ways of viewing their reality and a way to deal with it.

The awareness concerning some of the categories and themes highlighted in this study could be explored in group therapy context where the advanced psychiatric nurse practitioner could reflect on the influence mental illness has on the family.

The advanced psychiatric nurse practitioner could also reflect on some feelings the family experience and encourage them to verbalise those, as well as their use of defense mechanisms and what meaning and function these might serve.

Apart from the support from professionals (Edmonds and Wilcocks, 1995:64) it is important for these families to be able to verbalise their feelings within a support group for families with mentally ill family members. Families in group therapy can continue after therapy in a support group and meet once a month for mutual support and verbalising their needs and feelings. 
TABLE 3: Guidelines for support for families with mentally ill family members.

\begin{tabular}{|c|c|c|}
\hline Experience & Aim & Strategy \\
\hline $\begin{array}{l}\text { Shock related } \\
\text { The onset of mental illness in the family } \\
\text { as evidenced by the family } \\
\text { The family not accepting that the family } \\
\text { member is really mentally ill. }\end{array}$ & $\begin{array}{l}\text { To accept their mentally } \\
\text { ill family member without } \\
\text { any prejudice. }\end{array}$ & $\begin{array}{l}\text { Supportive counselling for the family; } \\
\text { this will enable them to verbalise and } \\
\text { express their feelings (Okun, 1992:142-149, } \\
\text { 220; Egan, 1986:139-140; Gerald, 1993: } \\
\text { 98-116; Corsini \& Wedding, 1989: } \\
\text { 155-196, 285-320; Brammer, Shortstrom \& } \\
\text { Abrego, 1989:94-96.) }\end{array}$ \\
\hline $\begin{array}{l}\text { Fright related to verbal and physical } \\
\text { aggression as evidenced by some of the } \\
\text { family members - running away from } \\
\text { home and looking for hiding places } \\
\text { elsewhere. }\end{array}$ & $\begin{array}{l}\text { To be relaxed and to be able } \\
\text { to take constructive action. }\end{array}$ & $\begin{array}{l}\text { Edmonds \& Wilcocks ( } 1995: 64) \text { suggest } \\
\text { that families should remain calm, seek } \\
\text { professional help from doctors, counsellors } \\
\text { and psychologists. } \\
\text { Talk to someone about how they feel } \\
\text { and join support groups for families in the } \\
\text { same situation. }\end{array}$ \\
\hline $\begin{array}{l}\text { Anger related to assault from the mentally } \\
\text { ill family member as evidenced by the } \\
\text { family members. } \\
\text { Not accepting the mentally ill back home. }\end{array}$ & $\begin{array}{l}\text { To be able to channel anger the } \\
\text { correct way. }\end{array}$ & $\begin{array}{l}\text { Encourage the family to release their anger } \\
\text { verbally in the safety of a psychiatric } \\
\text { nursing specialist's environment. } \\
\text { Teach them how to channel their anger in } \\
\text { future (Geldard, 1993:150-151). }\end{array}$ \\
\hline $\begin{array}{l}\text { Isolation from significant others, other } \\
\text { families and friends related to destructive } \\
\text { behaviour of the mentally ill family } \\
\text { member as evidenced by their family. } \\
\text { Not visited by people. }\end{array}$ & $\begin{array}{l}\text { To have lasting relationships and } \\
\text { to rebuild the lost ones. }\end{array}$ & $\begin{array}{l}\text { Families should build relationships within } \\
\text { themselves. During counselling sessions } \\
\text { they should be able to learn how to } \\
\text { handle negative relationships and to } \\
\text { verbalise and express their feelings. } \\
\text { Families should be encouraged to attend } \\
\text { support groups. } \\
\text { Johnson (1993:16) suggests the following } \\
\text { ways of finding positive relationships: } \\
\text { - Simply wait until someone finds you and } \\
\text { wants to be your friend. } \\
\text { - Simply ask other people to be your friend. } \\
\text { - Give your friendship to others. }\end{array}$ \\
\hline $\begin{array}{l}\text { Physical exhaustion related to lack of } \\
\text { sleep and restraining a person who wants } \\
\text { to run away as evidenced by them feeling } \\
\text { sleepy and looking tired. }\end{array}$ & $\begin{array}{l}\text { To rest mentally, physically } \\
\text { emotionally and socially. }\end{array}$ & $\begin{array}{l}\text { The family members are advised to } \\
\text { take turns in caring for the mentally } \\
\text { ill family member. } \\
\text { To seek help from professional people. } \\
\text { To have a person admitted if out of control. } \\
\text { This is done to safeguard both the family } \\
\text { member and the mentally ill member from } \\
\text { over-exhaustion. } \\
\text { No literature to support this. }\end{array}$ \\
\hline $\begin{array}{l}\text { Distrust, uncertainty and insecurity related } \\
\text { to previous assaults as evidenced by no } \\
\text { acceptance of the member back home. }\end{array}$ & $\begin{array}{l}\text { Rebuild broken trust. } \\
\text { Feel secure. }\end{array}$ & $\begin{array}{l}\text { Families who confront the situation } \\
\text { in an honest, open manner, talking about } \\
\text { their own helplessness, guilt, fear and anger } \\
\text { are more likely to gain the member's trust } \\
\text { (Bescher \& Friedman, 1986:188). }\end{array}$ \\
\hline $\begin{array}{l}\text { Denial related to disbelief that has } \\
\text { occurred in the family as evidenced by } \\
\text { avoiding reality. }\end{array}$ & $\begin{array}{l}\text { Acceptance of their mentally } \\
\text { ill family member. }\end{array}$ & $\begin{array}{l}\text { The time to act is now. Do not waste time } \\
\text { by saying it cannot happen in my family. } \\
\text { Seek professional help. Find more informa- } \\
\text { tion on mental illness. Join support groups } \\
\text { immediately (Okun, 1992:149-220; Corsini } \\
\& \text { Wedding, 1989:155-196). Attend group } \\
\text { therapy (Yalom, 1985:456-485). "To be } \\
\text { able to start acting constructively and with } \\
\text { strength and conviction, you will have to } \\
\text { stop fooling yourself" (Searll, 1995:128). }\end{array}$ \\
\hline
\end{tabular}




\section{Experience: Second stage - Family take action}

The family members seek help for their mentally ill family member in a desperate attempt to cope with the effect this has had on the family. The family experiences different emotions like fear and doubt, frustration and many other negative emotions that they find difficulties in dealing with. They also experience a tremendous amount of physical exhaustion due to the fact that they do not sleep and rest properly.

\section{Aims}

- To be able to verbalise negative feelings as relief of emotional stress.

- To be able to channel negative energy in a more constructive way.

- To be able to rest more (physical, emotional and social).

- Rebuild broken trust and feelings of security.

In the group therapy, many of the above stated negative feelings will be addressed as discussed in the previous stage. During counseling sessions families will able to learn how to deal with negative relationships and to verbalise and express their feelings, as this is the first step in recognising the effect that these negative feelings can have on relationships within the family (Johnson, 1993:16). Johnson (1993:16) also describes valuable tips for establishing new relationships in this difficult situation. (See table 3.)

When family members are exhausted, they tend to be more negative and fail to take good care of their mentally ill family member. They should take turns to care for the patient and make sure that they also have enough time for them to prevent burnout. It is important that they know the signs of relapse so that the patient can be admitted to the hospital if necessary. If the patient could be admitted in time, it could also safeguard the family from unnecessary strain and exhaustion.

\section{Experience: Stage three - Discharge from hospital}

Most of the themes of the third stage have already been discussed, but the effect of the discharge of the mentally ill family member's on social relationships and isolation will shortly be discussed. (See table 3 .)

\section{Aims \\ - Verbalise feelings \\ - Acceptance of mentally ill family members \\ - Support in the form of support groups and group therapy}

Mental illness can destroy family relations and create havoc within families. It can escalate in such a way that these families do not want their mentally ill family member back at home. They then try to avoid the situation and this causes more stress within the family. The most important thing for families is to be able to recognise what is happening within their families and to be able to understand the process. They need to seek professional help and gain more information about the illness and the process of mental illness and the effect thereof on the family. Family psycho-education is of vital importance, where family members are taught to deal with mental illness, recognise the signs and symptoms of relapse, deal with medications and recognise the side effects thereof, manage the side effects of medication and the negative feelings of anger and mistrusts of the patient. Once the family is more secure about these aspects, they would feel safer in managing the patient at home. The role of support groups is vital in their understanding of the process (Okun, 1992:149-220; Corsini, 1998:115-196).

The advanced psychiatric nurse practitioner should make her-/himself available after termination of the last session should the group require further discussion and/or individual family therapy. Yalom (1985:464) describes the fact that talking in a group helps and that relief is to be gained from sharing pain and being heard, understood and accepted by others.

\section{REFERENCES}

Aviram, U 1990: Community care of the seriously mentally ill. Continuing problems and current issues. Community Mental Health Journal, 26(1), February 1991:65-85.

Beschner, GM \& Friedman AS 1986: Teen drug use. Lexington, Massachusetts: Lexington Books.

Brammer, LM; Shostrom, EL \& Abrego, PJ 1989: Therapeutic psychology: Fundamentals of counseling and psychotherapy. London: Prentice-Hall International Editions.

Burns, N \& Grove, SK 1993: Practice of nursing research: Conduct, critique and utilization. Philadelphia: WG Saunders.

Center For The Study Of Health Policy: University of the Witwatersrand 1991: The need for the improved mental health care in South Africa. Nursing RSA, (1), 1991.

Corsini, RJ \& Wedding, D 1989: Current psychotherapies; fourth edition. Belmont California: Peacock Publishers.

Cresswell, JW 1994: Research design: Qualitative and quantitative approaches. California, London, and New Delhi: Sage Publications.

Department of Nursing 1993: Nursing for the Whole Person Theory. Johannesburg: Rand Afrikaans University.

Edmonds, L \& Wilcocks, L 1995: Teen drug scene - South Africa: A guide for parents and schools. South African Journal of Psychology, 25(4). 
Fawcett, CS 1993: Family Psychiatric Nursing. St. Louis, Missouri: Mosby.

Geldard, D 1993: Basic personal counseling. London: Prentice-Hall.

Goldenberg, I \& Goldenberg, H 1991: Family therapy: An overview. California: Pacific Grove.

Haber, J; Hoskins, PP; Leach, AM \& Sideleau, BF 1987: Comprehensive psychiatric nursing; third edition. New York: McGraw Hill.

Johnson, DW 1993: Reaching out: Interpersonal effectiveness and self-actualization; fifth edition. United States of America: Allyn and Bacon.

Kerlinger, F 1986: Foundation of behavioral research. New York: $\mathrm{HOH}$, Renehart and Winston.

Krefting, L 1990: Rigor in qualitative research: The assessment of trustworthiness. The American Journal of Occupational Therapy, 45(3), March 1991:214-222.

Kvale, S 1983: The qualitative research interview: A phenomenological and hermeneutic model of understanding. Journal of Phenomenological Psychology, (14), 1983:171196.

Madela, EN 1994: A model for culture-congruent psychiatric nursing (D.Cur-thesis). Johannesburg: Rand Afrikaans University.

Mbiti, JS 1991: Introduction to African Religion. London: Heinemann

Mouton, J \& Marais, JC 1990 \& 1992: Methodology of social sciences: Basic concepts. Pretoria: Human Sciences Research Council.

New Health Act 1997: White paper for the transformation of the health system in South Africa. Pretoria: Department of Health.

Okun, BF 1992: Effective helping: Interviewing and counseling techniques; fourth edition. California: Brooks/Cole Publishing Company.
Omery, A 1993: Phenomenology: A method for nursing research. Advances in Nursing Science, 5(2), January 1993:49-63.

Perko, JE \& Kreigh, HZ 1988: Psychiatric and mental health nursing; third edition. Connecticut: Appleton and Lange.

Poggenpoel, M 1990: Psychiatric nursing model. An interaction approach focussed on facilitating a patient's quest for wholeness. Johannesburg: Department of Nursing, Rand Afrikaans University.

Rand Afrikaans University, Department of Nursing Science 1992: Nursing for the Whole Person Theory. Auckland Park: Rand Afrikaans University.

Rawlins, RP; Williams SR \& Beck CK 1993: Mental Health Psychiatric Nursing. A Holistic Life Cycle Approach; third Edition. St Louis: Mosby.

SANA 1991: Ethical standards for nurse researchers. Pretoria: SANA.

Searll, A 1995: Get high on life: beating drugs together - a guide for teenagers, parents and teachers. Wynberg: Zebra

Stuart, GW \& Sundeen, SJ 1991: Principles and practice of psychiatric nursing; fourth edition. St Louis: CV Mosby.

Uys, LR \& Zulu, RN 1996: An evaluation of the implementation and the effectiveness of case management in the rehabilitation of psychiatric outpatients in South Africa. South African Journal of Psychology, 26(4),1996:226-230.

Van Reenen, G 1994: Attitudes and crew support programs. Air Asia, (6), October 1994:84-87.

Wilson, HS 1989: Research in Nursing; second edition. Redwood City, California: Addison-Wesley.

Wilson, HS \& Kneisl, CR 1988: Psychiatric nursing: third edition. Menlo Park, California: Addison-Wesley.

Woods, NF \& Catanzaro, M 1988: Nursing research, theory and practice. St Louis: Mosby.

Yalom, AD 1985: The theory and practice of psychotherapy; third edition. New York: Basic Books. 